Article

\title{
Current Status, Barriers and Development Perspectives for Circular Bioeconomy in Polish South Baltic Area
}

\author{
Dariusz Mikielewicz, Paweł Dąbrowski *[D, Roksana Bochniak and Aleksandra Gołąbek (i)
}

Faculty of Mechanical Engineering, Department of Energy and Industrial Apparatus, Gdańsk University of Technology, 80-233 Gdańsk, Poland; dariusz.mikielewicz@pg.edu.pl (D.M.); roksana.bochniak@pg.edu.pl (R.B.); aleksandra.golabek@pg.edu.pl (A.G.)

* Correspondence: pawel.dabrowski@pg.edu.pl; Tel.: +48-0058-347-2285

Received: 5 October 2020; Accepted: 29 October 2020; Published: 3 November 2020

check for updates

\begin{abstract}
The following article presents the current legal situation in Poland as well as in the European Union. Data on biomass production in the Polish South Baltic area were analyzed, along with an indication of the key sectors for the development of bioeconomy. Presentation of the current state of biomass management was made and areas necessary for development were indicated to facilitate the sustainable management of biomass and waste generated during its processing. Differences between regions in the Polish South Baltic Area show how an individual approach in each of these areas is required. During the analysis, the most important barrier to the implementation of the circular economy was distinguished, which is the lack of an appropriate legal framework. This is to be changed by the Circular Economy Road Map, adopted in 2019.
\end{abstract}

Keywords: bioeconomy; Poland; law

\section{Introduction}

The dynamic development of the world economy not only influences the constantly increasing standard of living but also has a negative impact on the natural environment, which undoubtedly also affects human life. Climate changes are becoming more visible, and reducing it is now one of the most urgent issues raised in the world-decisions are made not only at the national level but also internationally. In order to decrease worldwide the negative impact of technological development on the environment, it becomes necessary not only to minimize the emission of pollutants or reconstruct energy systems but also to change the entire approach to the production of a single detail-starting from the design level, which must predict the environmental impact of a given product, through its production with a minimized negative impact on the environment and the final waste management. Due to that, increased efforts are being exercised to develop the concept of the circular bioeconomy, which combines the idea of bioeconomy and circular economy.

As defined in the EU Updated Bioeconomy Strategy [1], the term "bioeconomy" includes all branches of the economy that use or produce biological resources. The development of bioeconomy is currently a global trend that is to ensure safety and access, above all, to food, energy, water, and raw materials, as well as ensuring their efficient use [2]. Therefore, it can be noticed that for the present and future generations, this issue is very important, and activities in line with the idea of bioeconomy may have a decisive impact on quality of life. The most important components of the bioeconomy are sustainability and circularity. Sustainability refers to managing the environment in such a way that satisfying the needs of today's generations does not negatively affect the lives of future generations. Great emphasis is placed on the sustainable management of natural resources-at present, efforts are 
being employed to use as much as possible renewable raw materials, and thus limit the use of raw materials whose resources are still running out. The effect of this approach is primarily to reduce the emission of harmful compounds into the atmosphere (mainly carbon dioxide), which is to prevent further global warming, and this will have a positive effect on our lives and future generations. Sustainable development is an important and an international issue, which is regulated by law, among others in the provisions of the Paris Agreement [3] and its Climate objectives, as well as the 2030 Agenda for Sustainable Development and its Sustainable Development Goals [4].

The second pillar of bioeconomy is circularity. It is based on the use of biomass-based waste from agro-industrial chains to produce valuable products from them. As a result, it is possible to significantly reduce the amount of produced waste. The scheme of such action is, for example, cited in the Updated Economy Strategy - by using some waste from the livestock industry (properly and according to the adopted requirements) and producing animal feed from them, it is possible to reduce the area intended for bringing up animal feed and to use this area for the cultivation of the feedstock used for fulfilling the demand for human food [1].

Circularity is the basis of the circular economy concept. This, despite many years of discussions and activities, is yet not precisely specified, and in the literature, there are presented as many as 114 definitions [5]. The analysis of these definitions allowed us to specify one meta-definition: "A circular economy is an economic system that replaces the 'end-of-life' concept with reducing, alternatively reusing, recycling and recovering materials $\mathrm{n}$ production/distribution and consumption processes" [5,6]. The circular economy is the opposite of a linear economy, which has led to an imbalance between resource supply and goods demand, which in turn made it impossible to regenerate the natural environment due to the excessive extraction of natural raw materials [7,8]. Additionally, there are still many barriers (for example, cultural barriers, company culture, particularly a lack of consumer interest and awareness as well as a hesitant company culture) that limit the transformation towards the circular economy [9]. It should be noted, that the circular economy is not the same as the idea of bioeconomy, and some differences should be considered (mainly it concerns the fact that it is not possible to recycle some products, for example, cosmetics, paints, etc., and carbon dioxide generated in energy processes prior to its utilization, it cannot be said that the circular economy condition is met) [10].

Ideas of bioeconomy and circular economy are combined by the concept of the circular bioeconomy, which is described as "the meeting point of the bioeconomy and the circular economy, integrating common goals, such as sustainability and resource efficiency with a low carbon footprint" [10]. The European Union, wishing to achieve a resource-efficient biomass use, continues to create new strategies in which it is considering a transformation towards circular bioeconomy [11].

The article is aiming to present the status of readiness of the Polish South Baltic Area for the introduction of the bioeconomy. The discussion hence comprised the review of the law regulations regarding bioeconomy in the European Union and Poland, followed by the main types of biomass available in the Polish SBA Region. Discussed are Polish Regional Operational Programs in the years 2014-2020 and their impact on the Polish bioeconomy.

\section{Law Regulations}

\subsection{Law Regulations on Bioeconomy in the European Union}

The European Union has been a leader in the combat against climate change and environmental issues for years. Member States are striving to develop the economy, respecting natural resources and ecosystems to meet the challenges of the 2030 Agenda and its Sustainable Development Goals, the EU's commitments under the Paris Agreement, and the targets of the 2030 Climate and Energy Framework. The European Commission is constantly creating new strategies related to the development of a sustainable bioeconomy that will contribute to fulfilling the provisions of the 2030 Agenda and the Paris Agreement, which are the base of the international cooperation on climate change. These new 
documents are increasingly advanced and contain more precise information on good practices, which the main goal is to reduce greenhouse gas emissions and preserve biodiversity in the European Union. In October 2018, the Updated Bioeconomy Strategy came into force, which is based on the 2012 Bioeconomy Strategy, and the results of its reviews. The Updated Strategy underlined that sustainable bioeconomy activities have been recognized as a central, to meet the Sustainable Development Goals [1]. It has the Action Plan, which sets out in detail the path to be followed to ensure the further development of a sustainable and circular bioeconomy. The Action Plan focuses on five objectives [1]:

- ensuring food and nutrition security,

- managing natural resources sustainably,

- $\quad$ reducing dependence on non-renewable, unsustainable resources whether sourced domestically or from abroad,

- mitigating and adapting to climate change,

- strengthening European competitiveness and creating jobs.

These goals are represented by three main actions, which include 14 special sub-actions [1]. The first action is aimed at accelerating the development of sustainable and circular biomass-based solutions in Europe, mainly by accelerating the development of biomass-based solutions in Europe, increasing the number of stakeholders involved in the development of these solutions and by supporting these activities differently, for example by launching of the EUR 100 million Circular Bioeconomy Thematic Investment Platform under Horizon 2020. The second act focuses on deploying local bioeconomy across Europe, mainly by developing a Strategic Deployment Agenda, supporting Member States and regions to develop Bioeconomy Strategies and promoting different activities regarding bioeconomy. The last action is based on understanding the ecological boundaries of the bioeconomy. The aim of this action is to increase awareness about biodiversity and ecosystems and ecological limits.

The latest plan, which is very important in the context of bioeconomy is The European Green Deal, which was presented in December 2019. The goal of the actions described in the document is to become by 2050 a continent that is climate neutral [12]. To implement this provision, the presented plan focuses on the transition from a linear economy to a circular economy, as well as caring for biodiversity and reducing pollution. This involves undertaking a number of initiatives that the European Green Deal Annex specifies. In March 2020, the Circular Economy Action Plan for a cleaner and more competitive Europe was presented, which is based on the European Green Deal. One of the sub-actions of this document is supporting sustainable and circular bio-based sectors by the implementation goals presented in the Bioeconomy Strategy and its Action Plan [13]. Furthermore, different strategies such as The Farm to Fork Strategy and EU 2030 Biodiversity Strategy, which are connected with the bioeconomy, are under development.

Each country in the European Union places a different emphasis on bioeconomy. The law is enacted individually on the basis of recommendations issued by the relevant bodies of the European Union. For this reason, the situation of the bioeconomy in each country of the European Union differs from one another. Some countries have a Dedicated Bioeconomy Strategy, others are just developing it, and others have only strategies. A summary is presented in Table 1.

Table 1. The situation of bioeconomy in the European Union [1].

\begin{tabular}{cc}
\hline Policy & EU Country \\
\hline Dedicated Bioeconomy Strategy at national level & Spain, France, Italy, Germany, Finland, Latvia, Ireland \\
\hline $\begin{array}{c}\text { Dedicated Bioeconomy Strategy at national level under } \\
\text { development }\end{array}$ & $\begin{array}{c}\text { The United Kingdom, The Netherlands, Austria, Hungary, } \\
\text { Lithuania, Estonia, }\end{array}$ \\
\hline Other policy initiatives dedicated to the bioeconomy & $\begin{array}{c}\text { Belgium, Denmark, Poland, Sweden, Czech Republic, } \\
\text { Slovakia, Slovenia, Croatia, Romania, Bulgaria }\end{array}$ \\
\hline Other related strategies at the national level & Portugal, Luxembourg, Malta, Greece, Cyprus \\
\hline
\end{tabular}




\subsection{Law Regulations on Bioeconomy in Poland}

Poland is one of the countries that currently do not have a dedicated Bioeconomy Strategy at the national level, but there are some documents that take into account issues relevant to the development of bioeconomy at the national but also at the regional level. They are mainly based on supporting activities aimed at sustainably developing the country, which is one of the principles of bioeconomy. Guiding by the principle of sustainable development is dictated by the most important document in Poland, which is the Constitution of the Republic of Poland. The fifth article of this document states that the state guards the national heritage and protects the environment, guided by the principle of sustainable development [14]. In turn, the definition of this term according to Polish law is quoted in the Act on Environmental Protection and states that it is socio-economic development in which political, economic and social activities are integrated with the preservation of natural balance and basic natural processes to guarantee the possibility of satisfying basic needs of the communities and citizens of present and future generations [15]. The principle of sustainable development is the most important issue during drawing up various concepts and spatial development plans for the country and individual regions, as well as development strategies for these regions.

In 2017, the Strategy for Responsible Development up to 2020 with a perspective until 2030 was announced [16]. This document is an update of the National Development Strategy 2020 and is a key document related to the economic policy of the Polish state. It is strongly associated with the 2030 Agenda and its Sustainable Development Goals and meets the expectations formulated in the Agenda. The strategy has three main objectives:

- Sustainable economic growth based increasingly on knowledge, data and organizational excellence;

- Socially sensitive and territorially sustainable development;

- An effective state and institutions serving the growth and social and economic inclusion.

Based on the above document, nine integrated strategies have been created, where these issues are specified, including the National Strategy for Regional Development 2030, Ecological Policy of the State 2030, and the Strategy for Sustainable Development of Rural Areas, Agriculture and Fisheries 2030, which are important in the development of Polish bioeconomy.

In September 2019, the National Strategy for Regional Development 2030 was announced. It is the basic strategic document of Poland's regional policy until 2030 and underlines the sustainable development of the entire country, supporting individual regions to reduce disparities in the level of their development [17]. One of the challenges of the presented strategy is an adaptation to climate change and minimizing threats to the environment. Taking into account the specificity of each region, appropriate solutions should be introduced that will serve to preserve biodiversity and to develop the bioeconomy and "green innovations". Such activities aim to improve the quality of life and protect the most valuable natural areas, which have an impact on the fight against adverse climate change. The strategy also emphasizes the need to develop waste management in such a way as to introduce a circular economy that seeks to maximize the use of waste as raw materials in new processes, thus counteracting food waste. This, in turn, is associated with the creation of innovative projects for the recycling of waste and its selective collection, as well as installations for the processing of biowaste, adapted to the specificity of the region.

Another document is the 2030 Ecological Policy of the State, which is a development of the environmental part of the Strategy for Responsible Development and implements 11 of 17 Sustainable Development Goals [18]. Its main goal is to develop the potential of the environment for the benefit of citizens and entrepreneurs. Specific objectives, in turn, are related to health, economy and climate, focusing, among others, on the elimination of sources of air pollution, improvement of biodiversity in the country and the introduction of a circular economy. The implementation of the 2030 Ecological Policy in the field of a circular economy is supported by the National Waste Management Plan 2022 [19]. The foundation of this document is the Waste Act, in which are described definitions of the basic terms used to refer to waste in the bioeconomy approach [20]: 
- biowaste-garden and park waste, food and kitchen waste from households, gastronomy, mass caterers and other units producing or marketing food that is biodegradable, i.e., aerobic or anaerobic digestion with the presence of microorganisms;

- green waste-municipal waste which are parts of plants from the care of green areas, gardens, parks, and cemeteries, as well as from marketplaces, excluding waste from cleaning streets and squares.

The 2030 strategy for the Sustainable Development of Rural Areas, Agriculture and Fisheries is also a key document from the point of view of Polish bioeconomy. Its main plan is the implementation of the second goal of the 2030 Agenda, namely, to eliminate hunger, achieve food security and better nutrition and promote sustainable agriculture [21]. It emphasizes the importance of creating national systems for sustainable food production, adapting agriculture to a changing climate and ensuring plant and animal biodiversity. The strategy also implements at different levels other Sustainable Development Goals, as well as the individual goals of the 2030 Agenda.

In addition, each of the 16 regions (voivodeships) of Poland has a separate, dedicated development strategy, which focuses on one territory and is oriented in such a way that it is possible to introduce changes on which individual local governments have a real impact, and this will subsequently translate into the development of the whole country. These strategies take into account the specificity of individual territories within a given region and indicate that each challenge may have different nature and be easier or harder to perform.

However, it is worth remembering that Poland as a member state of the European Union must endorse provisions and regulations issued by the European Parliament. All strategies that are created by the European Commission and approved by the member countries must be reflected in national regulations, and thanks to that joint work can be done to protect the climate and the environment, as well as sustainable development.

\section{Major Types of Agricultural Biomass in Polish SBA}

The South Baltic Area (SBA) in Poland consists of three regions, that is West Pomerania, Pomerania, Warmia and Mazury. The regions differ from each other in terms of land area, population, size of agricultural areas, the share of individual farm sizes and the main production types. Furthermore, all the statistical data and considerations are related to the year 2018.

The total area (and population) of West Pomerania, Pomerania, Warmia and Mazury Regions are, respectively, 2,289,732 ha (1,701,030 people), 1,832,193 ha (2,333,523 people) and 2,417,347 ha $(1,428,983$ people) [22-24]. The diversity of area groups is shown in Figure 1 [25-27]. The use of arable land in individual regions is presented in Table 2 [25-27]. As can be deduced, the land area of agricultural holdings covers $38.2 \%, 45.5 \%$ and $43.6 \%$ of the entire West Pomeranian, Pomeranian and Warmia and Mazury region area, respectively.

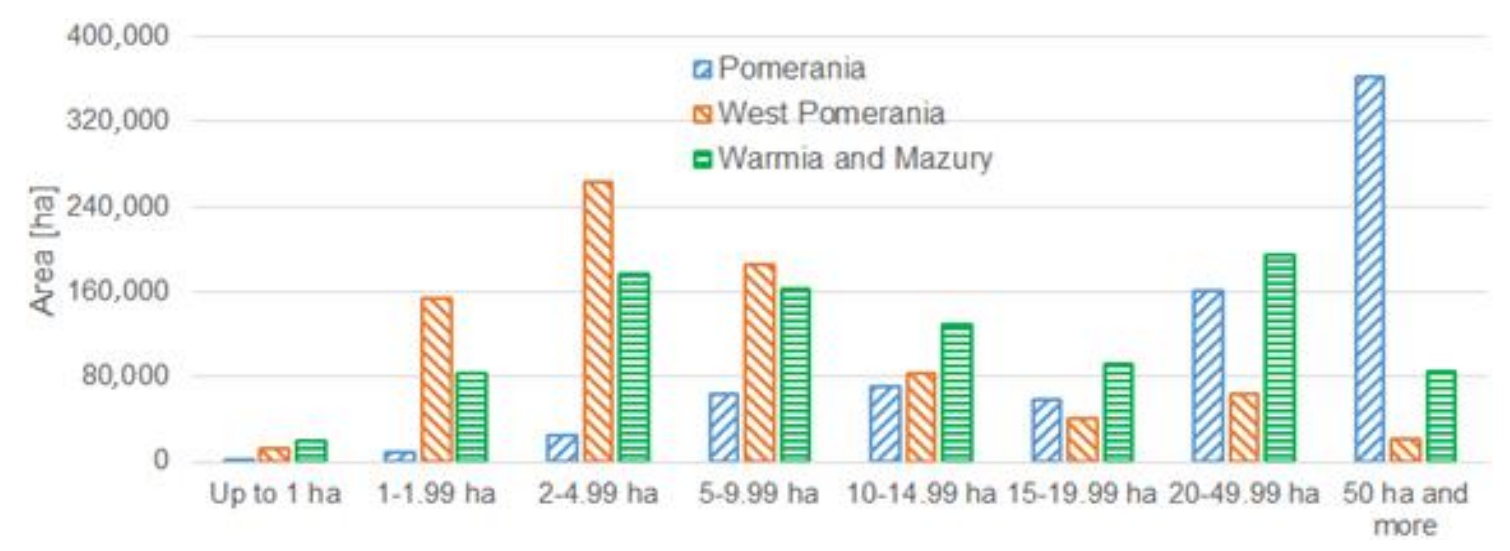

Figure 1. Farms by area group in Polish South Baltic Area (SBA) in 2018 [25-27]. 
Table 2. Agricultural land use in individual regions [25-27].

\begin{tabular}{ccccc}
\hline Region & $\begin{array}{c}\text { The Land Area of } \\
\text { Agricultural Holdings [ha] }\end{array}$ & Agricultural Land [ha] & Forests and Forest Land [ha] & Other Land [ha] \\
\hline $\begin{array}{c}\text { West } \\
\text { Pomerania }\end{array}$ & 874,354 & 824,934 & 17,396 & 32,023 \\
\hline Pomerania & 833,800 & 750,800 & 48,300 & 34,700 \\
\hline $\begin{array}{c}\text { Warmia and } \\
\text { Mazury }\end{array}$ & $1,053,000$ & 943,200 & 45,057 & 64,743 \\
\hline
\end{tabular}

As can be seen in Figure 1, SBA regions are diverse in farms by area group [25-27]. The largest area in the Pomeranian region is occupied by farms with a plot area of over 50 ha (48.2\%). Such farms significantly prevail in the region. The situation is different in the West Pomeranian region where the largest share in farms (32.0\%) belongs to those with a plot area ranging from 2 ha up to 5 ha. Moreover, the variation is not as big as in the Pomeranian region because farms with an area from 1 ha up to 2 ha and from 5 ha up to 10 ha have a share of $18.7 \%$ and $22.5 \%$, respectively. The Warmia and Mazury region is quite uniform in term of farms by the area group where most of the area group have a share of about $20 \%$ (2-4.99 ha, 5-9.99 ha, 20-49.99 ha) or about 10\% (1-1.99 ha, 10-14.99 ha, 15-19.99 ha, over $50 \mathrm{ha}$ ) in the total agricultural land. These data are crucial when thinking about biomass utilization. The market situation in the West Pomeranian region, where there are mainly small farms (up to $10 \mathrm{ha}$ ) is quite different from this in the Pomeranian region where the main share in the agricultural market is taken by farms with over 50 ha of land.

The total area of the region and the area of agricultural holdings and their area group diversity are not the only differences between regions in Polish SBA. Another one is the types of cereals that are sown. The total area under cereals in West Pomeranian, Pomeranian and Warmia and Mazury region is 437,447 ha, 422,859 ha and 385,872 ha, respectively. The main part of that area covers wheat (about $40 \%$ in every Polish SBA region). However, the differences between other cereals can be significant, e.g., the West Pomeranian region features almost twice a higher area with sown with rye than Warmia and Mazury region. On the other hand, the total area of cereal mixtures in West Pomeranian is about 2.5 times lower than in Pomeranian and Warmia and Mazury as well. The full analysis of the cereals area can be found in Figure 2 [25-27].

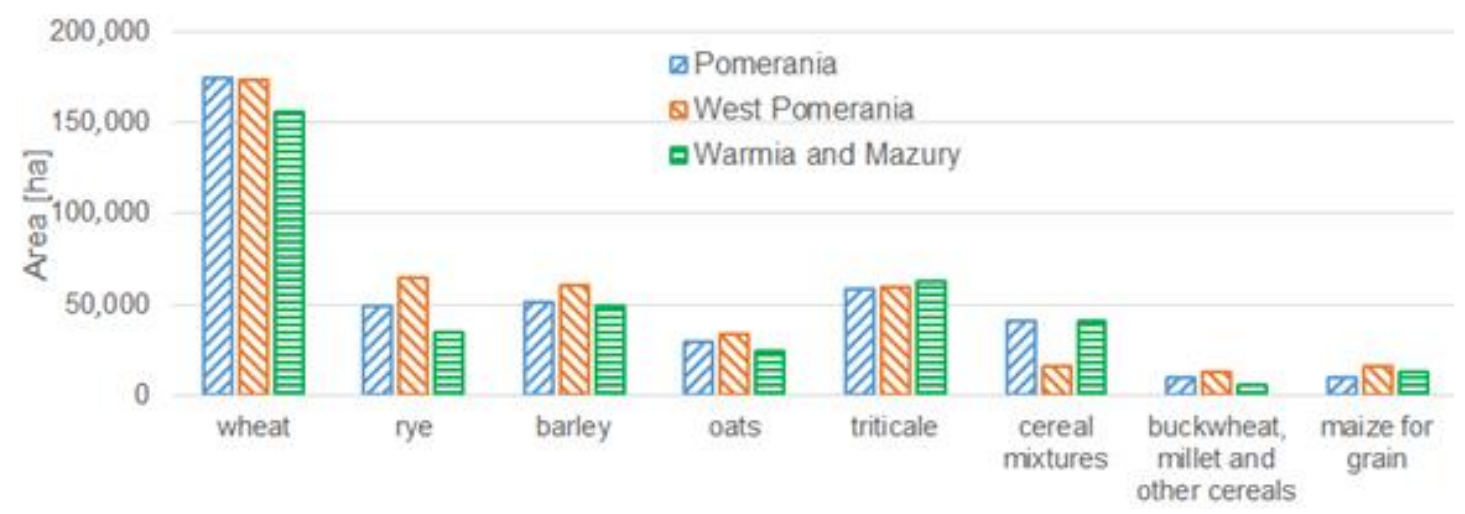

Figure 2. The area under various cereals in Polish South Baltic Area (SBA) in 2018 [25-27].

The sown area by crop groups in the Polish SBA region is shown in Figure 3 [25-27]. The main crop group in every region is cereals (from $65 \%$ to $70 \%$ ). The rest crop groups cover the area of 192,961 ha, 180,011 ha and 209,937 ha in West Pomeranian, Pomeranian and Warmia and Mazury region, respectively. The main group is feed crops in Warmia and Mazury (49.7\% of total sown area excluding the cereals) and industrial crops in West Pomeranian and Pomeranian $(49.7 \%$ and $39.6 \%$ respectively). The crop group of least interest in the Warmia and Mazury region is potatoes (only 1.5\% 
of the total sown area including the cereals). The Warmia and Mazury is 13th out of 16 regions in terms of potato production in Poland [28].

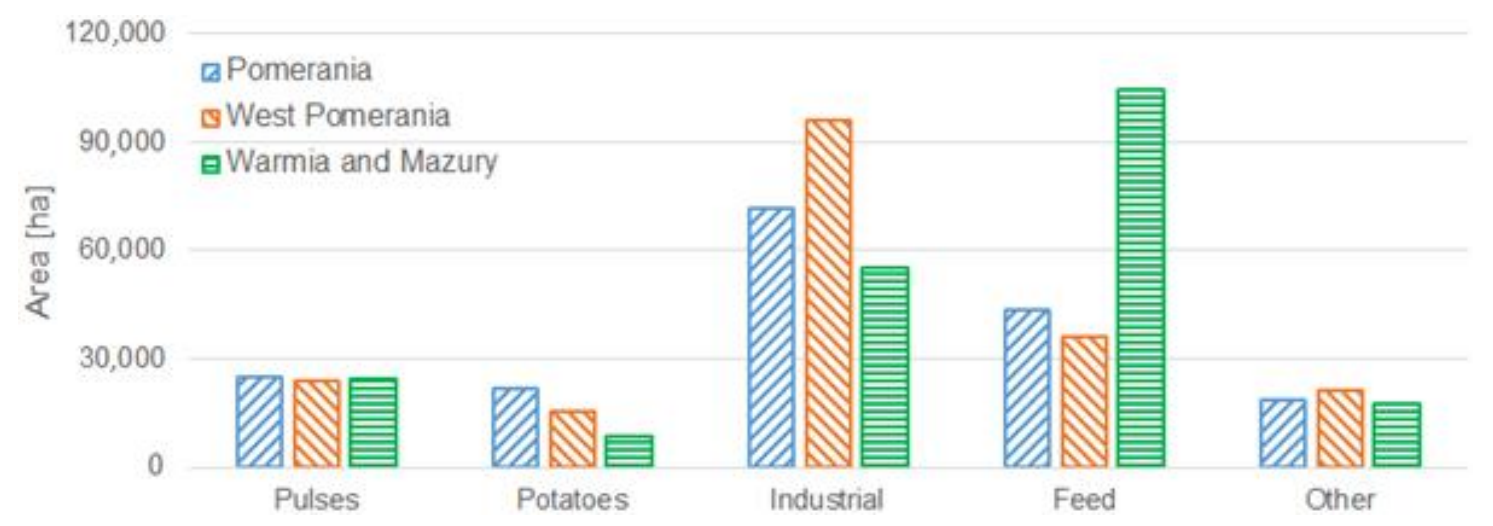

Figure 3. The sown area by crop groups in Polish South Baltic Area (SBA) in 2018 [25-27].

The main producer of potatoes in the Polish SBA region is the Pomeranian region (ranked 6th in Poland). The total sown area of this crop is 21,824 ha. The total production of potatoes in Pomeranian is 2.5 times bigger than in Warmia and Mazury. The analysis of yields and production of potatoes in Polish SBA regions is shown in Figure 4.

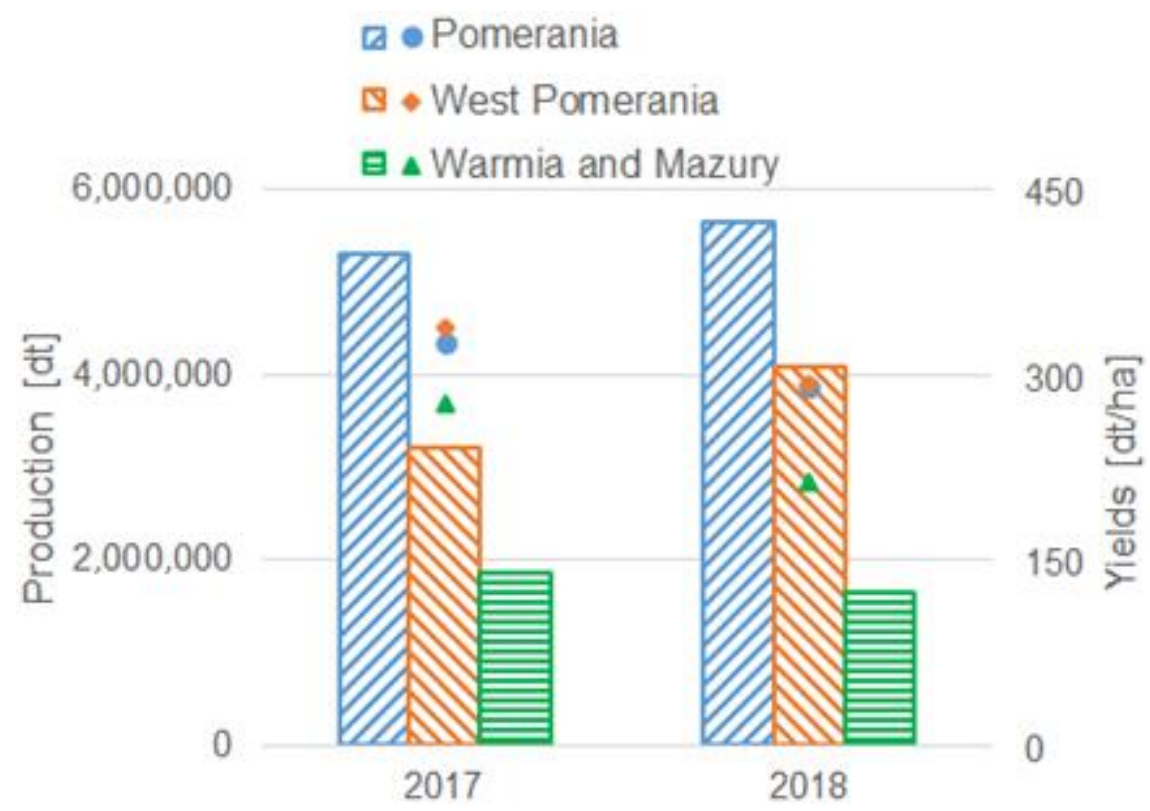

Figure 4. Yields and production of potatoes in the Polish South Baltic Area (SBA) in 2018. Bars refer to the left axis (Production) and points refer to the right axis (Yields) [25-27].

As can be seen in Figure 4 [25-27], the best yields in SBA are found in the Pomerania and West Pomerania Regions, whereas the worst are in Warmia and Mazury. It is not surprising that due to inadequate conditions for the production of potatoes (low yields), Warmia and Mazury produce the least of them in the entire SBA. However, the yields in the Pomerania and West Pomerania regions are similar to each other, yet in West Pomerania the production is about $28 \%$ lower.

Analyzing the yield and production of rape and turnip rape (Figure 5) in SBA [25-27] some surprising conclusions can be made. First of all, it can be seen that both the yields and production have been lowered in 2018 compared to 2017 by about $40 \%$. The lowest production is in Warmia and Mazury but the differences between regions are not as significant as in the case of potato production. Although the yields from each hectare in West Pomerania are the lowest (22 dt/ha in 2018), production in 
this region is still the highest. This is due to the larger crop area in this region. For comparison, the crop area in the Pomeranian Region in 2018 was 61,494 ha, while in the West Pomeranian Region it was 79,963 ha. The Pomeranian region is the 3rd voivodeship in Poland in the area of rape and turnip rape production [28].

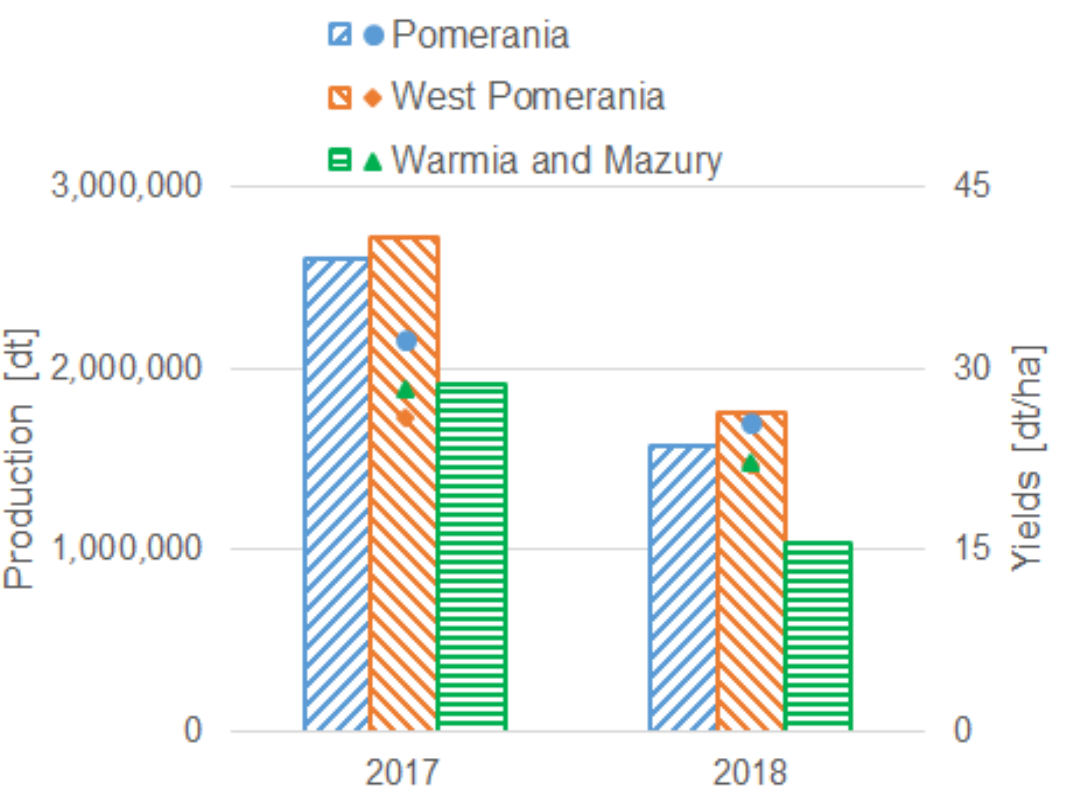

Figure 5. Yields and production of rape and turnip in the Polish South Baltic Area (SBA) in 2018. Bars refer to the left axis (Production) and points refer to the right axis (Yields) [25-27].

\section{Regional Operational Programs 2014-2020}

The necessity to reuse biomass is underlined many times nowadays. Osman et al. [29] emphasized that the essence is a change of thinking from "waste" to "resources"-after all, each waste can be used energetically at the end, which makes it always a kind of raw material. Most desirable is increasing the value of waste-i.e., up-cycling, according to the cascading approach (Figure 6). There are expert reports which confirm the improvement of the efficiency of the use of renewable resources through the cascading approach [30] and also research that shows that European bioeconomy cluster experts indicated the sector of bioplastics, pharmaceuticals as well as food and feed additives as the most promising future directions of bioeconomy development [11].

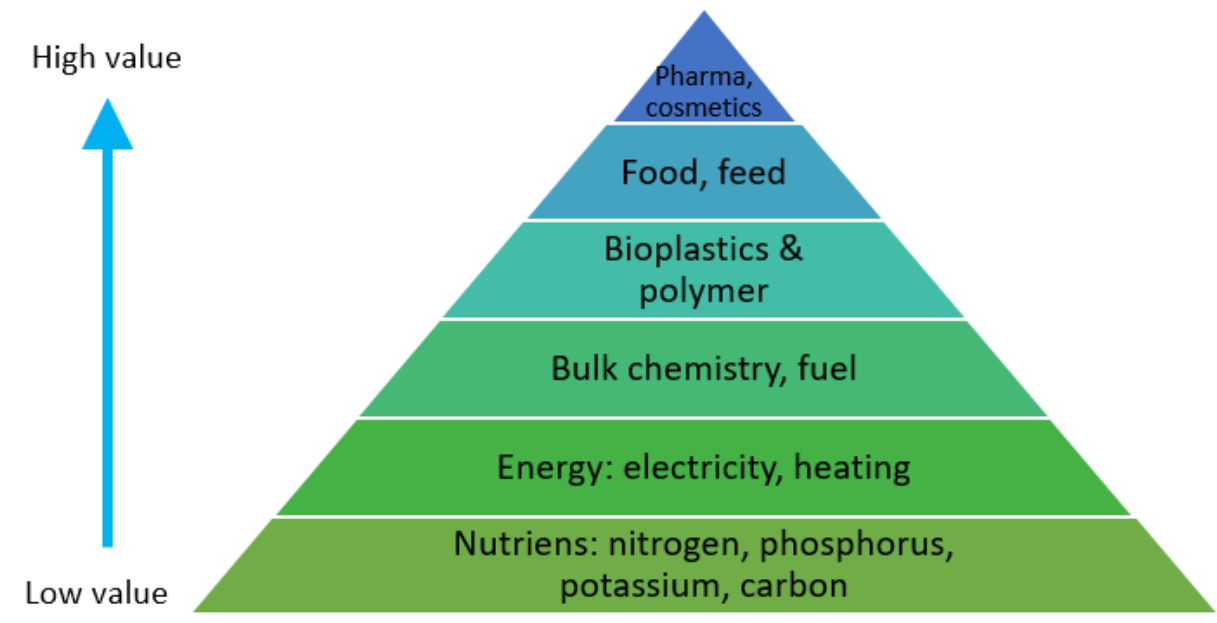

Figure 6. The cascading approach pyramid. 
In Poland, there are several forms of supporting and developing a circular economy and biomass valorization. There are numerous projects at universities concerning new biomass waste management technologies; however, most of them are yet in the implementation stage. Due to the diversity of natural resources in individual parts of Poland and the fact that each region has infrastructure at a different level, in Poland, there are dedicated regional programs tailored to the needs of specific areas.

Polish South Baltic Area regions have their Regional Operational Programs for years 2014-2020, under which it is possible to obtain funding for innovative projects crucial for the development of the region [31-33]. The programs co-finance projects from several priority axes, different for each region. Table 3 summarizes the priority axes for each of the regions examined in the article. The italic text indicates the priority axes, which include projects related to sustainable development, i.e., the circular economy and bioeconomy. They aim, among others, at supporting small and medium enterprises, development of new technologies, improvement of waste management, promotion of their reuse, implementation of waste recovery technologies and construction of infrastructure for the production and distribution of energy from renewable sources.

Table 3. Priority axes in SBA regions Regional Operational Programs [31-33].

\begin{tabular}{|c|c|c|c|}
\hline & West Pomerania & Pomerania & Warmia and Mazury \\
\hline \multirow{11}{*}{ Priority Axes } & $\begin{array}{l}\text { 1. Economy, innovations, modern } \\
\text { technologies }\end{array}$ & 1. Commercialization of knowledge & 1. Smart economy \\
\hline & 2. Low carbon economy & 2. Enterprises & 2. Staff for the economy \\
\hline & $\begin{array}{l}\text { 3. Environmental protection and } \\
\text { adaptation to climate change }\end{array}$ & 3. Education & 3. Digital region \\
\hline & 4. The natural surroundings of man & 4. Vocational training & \multirow{8}{*}{$\begin{array}{l}\text { 4. Energy efficiency } \\
\text { 5. Natural environment and } \\
\text { rational use of resources } \\
\text { 6. Culture and heritage } \\
\text { 7. Transport infrastructure } \\
\text { 8. Areas requiring revitalization } \\
\text { 9. Access to high-quality public } \\
\text { services } \\
\text { 10. Regional labor market } \\
\text { 11. Social inclusion }\end{array}$} \\
\hline & 5. Sustainable transport & 5. Employment & \\
\hline & 6. Labor market & 6. Integration & \\
\hline & 7. Social inclusion & 7. Conversion & \\
\hline & 8. Education & 8. Health & \\
\hline & \multirow[t]{3}{*}{ 9. Public infrastructure } & 9. Mobility & \\
\hline & & 10. Energy & \\
\hline & & 11. Environment & \\
\hline
\end{tabular}

According to the EU subsidy map [34], the SBA is currently financing: 11,736 projects in West Pomeranian Region (PLN 61,075,185,277.47), in Pomerania 14,970 projects (PLN 75,279,454,194.85), while in Warmia and Mazury Region 14,850 (PLN 59,596,511,647.43).

In the West Pomeranian Region, projects containing the keyword "biomass" mainly relate to the construction of biomass or biogas-fired installations (combined heat and power plants, heat plants, pyrolysis systems, modernization of existing heating systems) and are implemented for a total amount of approximately PLN 87 million. Several projects are being carried out on issues related to the reuse of waste (among others implementation of technology for the production of concrete precast using waste from wood biomass combustion, the technology of processing plastic and rubber waste into elements of road safety infrastructure or the use of slaughterhouse waste for the degradation of hydrocarbons). These projects amount to a total of approximately PLN 15 million [34]. In the Warmia and Mazury Region, the largest number of projects regarding the energy use of biomass are carried out from all SBA regions. Most projects co-financed by the European Union concern the modernization of existing installations to adapt them to biomass combustion or to increase the efficiency of biomass combustion devices. These projects are for a total amount of approximately PLN 407 million. Projects developing the reuse of post-production waste are also financed. Research is underway on the reuse of difficult-to-process waste for the production of soil stabilizing grates, and on the technology for recovering some raw materials from waste from the production of mineral-acrylic panels. These projects amount to approximately PLN 30 million [34].

The least number of projects related to the energy use of biomass is carried out in the Pomeranian Region, although they have a relatively large amount of funding (PLN 90 million). This amount is higher than in the West Pomeranian Region; however, almost PLN 85 million of this 
amount relates to the development of a single installation in an enterprise from the woodworking industry. The number of projects and funds allocated to the development of waste recycling technologies is the lowest among Polish SBA regions [34]. Figures 7 and 8 present estimated data collected based on a website providing data on co-financing under the Regional Operational Programs of the considered regions for the years 2014-2020 [34]. Data on the number of co-financing for highlighted purposes and the estimated number of projects carried out in a given field were presented. The presented data show the emphasis placed on building the basis for a circular economy, i.e., modernizing the energy system. The differences in co-financing result from the separate needs of the regions-the Warmia and Mazury area requires much greater financial outlays for the modernization and inclusion in the energy system of biogas plants and the energy use of biomass. There are the fewest projects in the Pomeranian region, both for the energy use of biomass and its reuse; however, this may be since this region is the most developed in the Polish Baltic Sea basin, so the funds are allocated to projects in less developed regions.

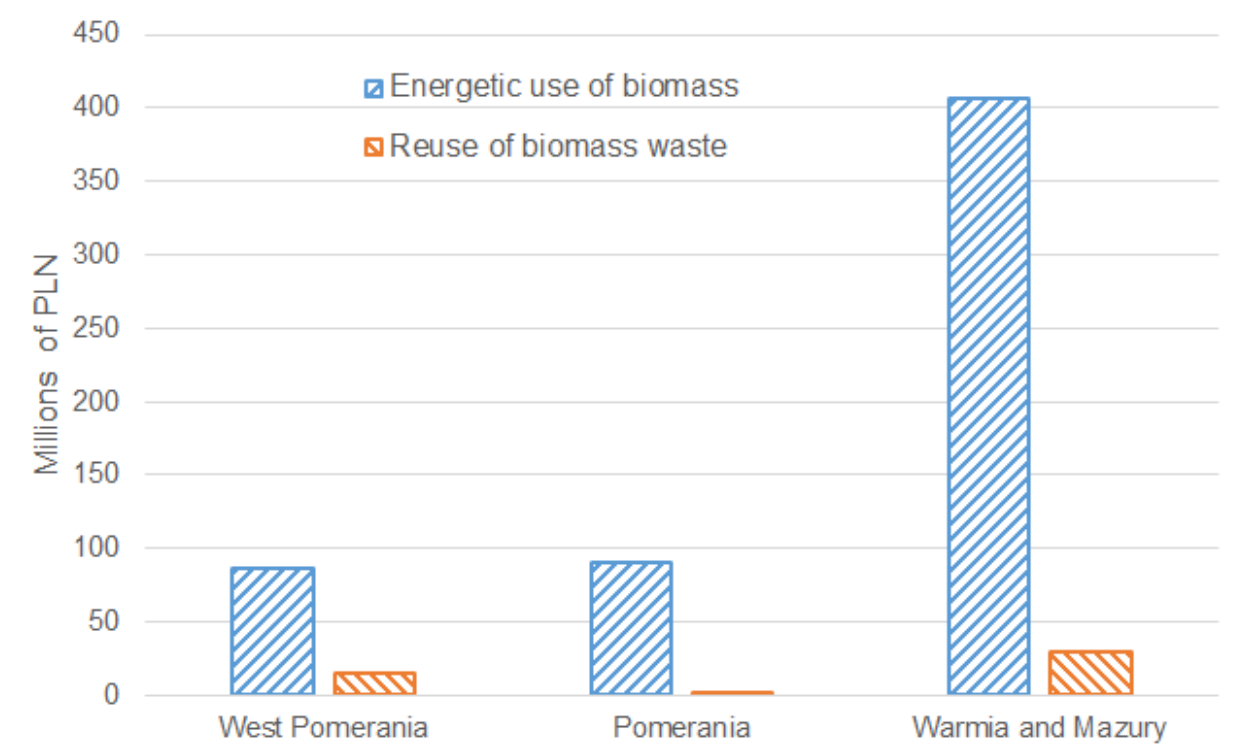

Figure 7. Financing amounts for projects related to biomass processing at SBA, Poland [34].

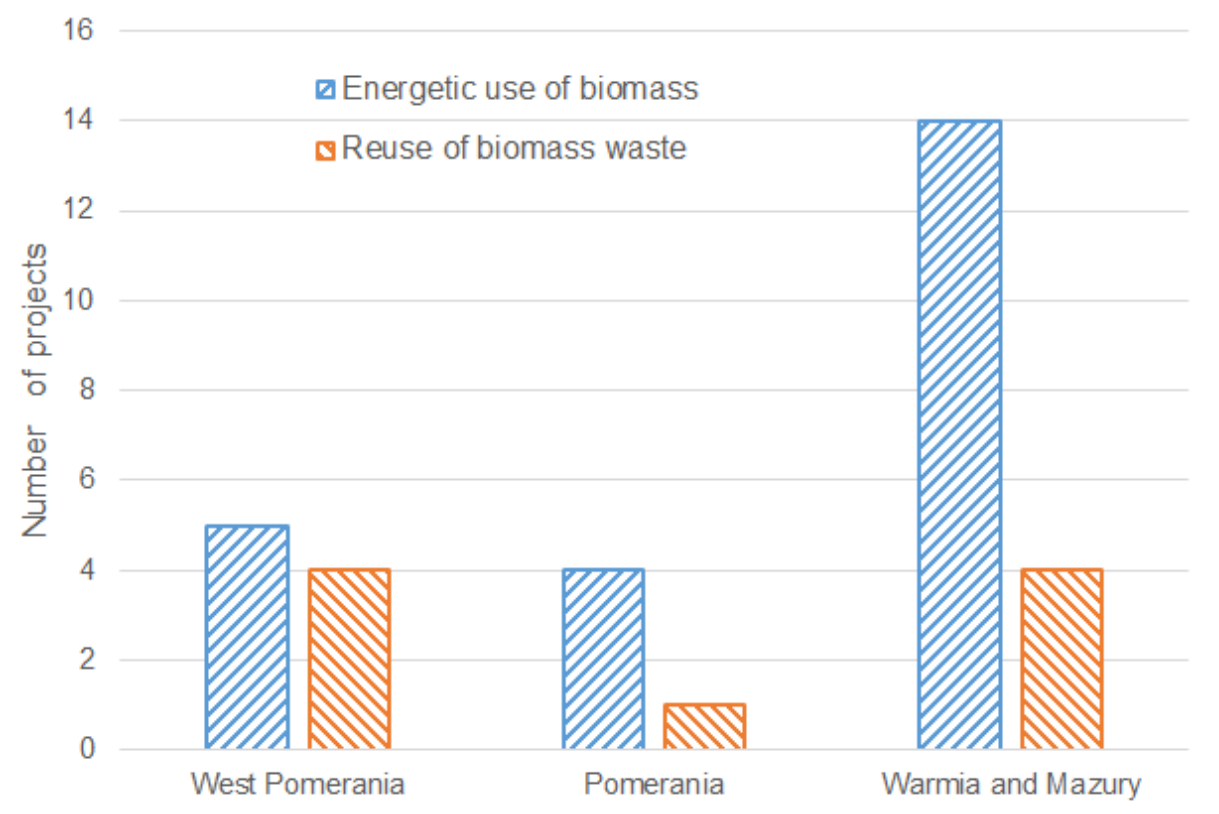

Figure 8. Number of projects related to biomass processing conducted in SBA, Poland [34]. 


\section{Discussion}

The presented data show the current status and possibilities in the Polish South Baltic area in the field of biomass reuse. The analysis of data on the number and size of farms as well as the type and quantity of raw materials shows numerous differences between regions and the need for an individual approach attempting to implement innovative technologies for the reuse of waste biomass. In the Pomeranian region, the majority of farms are 50 ha and larger. On the other hand, in the West Pomeranian region, most of the farms are up to 10 ha. Warmia and Mazury are characterized by a uniform structure of farms in terms of their size. It should be remembered that agricultural production in small farms differs from that on large farms. The volume of production is completely different and, thus, so is the amount of waste or by-product. Large farms in Pomerania would be a good place to start huge investments with a high rate of return but also with high risk. Due to the size of the farms, all ideas for the management of large amounts of waste can be implemented in the Pomeranian region. On the other hand, small pilot plants with low capacities will perform well in smaller farms. Smaller investment is a smaller business risk too. Besides, if there are several smaller farms in the neighborhood, it can be still reasonable to create a new company, which will manage waste from several nearby places.

Similarly, regions are diversified in terms of projects and implementation works carried out within them. The analysis of the allocated funds and the type of projects shows significant differences in the degree of modernization of the regions-in the Warmia and Mazury region there is a greater number of projects related to the development and modernization of the power grid. The Pomeranian Region, which has the most developed infrastructure in the field of renewable energy, is beginning to open up more to projects involving the reuse of biomass for the production of new goods, rather than its use for energy purposes. Therefore, it is important to adjust the introduced innovations in the field of new biomass utilization technologies to the degree of development of the region to equalize the opportunities as soon as possible.

The above situation is also influenced by the human factor. In order to take an active part in extending the biomass processing chain, farmers must recognize these practices as beneficial not only for the environment but also for themselves [35]. Many factors influence the perception of innovation and new technologies by farmers, including gender, property status and experience. Jiang et al. pointed out that highly educated, high-income farmers will be more willing to invest and participate in innovations in the field of biomass waste [35]. This may be related to the general level of farmer satisfaction-research on the economic situation on farms in the first half of 2019 showed that the most optimistic opinions about the economic situation came from farmers aged up to 24, with higher education and people running a farm for no longer than a year [36]. In general, farmers were pessimistic about the general situation of their farms and the profitability of agricultural production [36]. In such a situation, they probably will also not be interested in new products until their basic demands are met. The implementation of new biomass management technologies must, therefore, go hand in hand with raising awareness, education and the quality of life of farmers.

Polish South Baltic Regions have a great biomass valorization potential; however, the data presented above show how little is being done to use them for purposes other than energy. The basic problem in Polish law that blocks the implementation of innovations in the field of biomass residues is the status of waste. Procedures to be followed to be able to use waste as raw materials in subsequent processes are complicated and time-consuming. The problem is that to change this status, each case must be considered separately at the request of a given company, which significantly lengthens and complicates the process. This is a kind of challenge that may discourage producers from taking steps regarding the use of waste in the production process due to the fact that each new component/waste will require a separate clearance procedure. The examples of existing products fabricated from post-processing biomass waste show that it is possible in Poland to change the waste status; however, it should be remembered that there are only a few examples in the huge Polish market. A faster, generalized procedure for changing the waste status should therefore be possible. Since the waste 
material and the products made from it must be comprehensively tested in a laboratory, it would be beneficial to support entrepreneurs in terms of access to laboratories or co-finance research on the composition of their post-production waste.

Poland is starting to take the first steps to change the legal status in the field of bioeconomy, circular economy and waste from biomass processing. In 2019, Poland adopted the Circular Economy Road Map [37], prepared by the Ministry of Entrepreneurship and Technology. The road map contains suggestions for specific actions to develop this economy system in Poland. The main goal is a comprehensive change from a linear approach (raw material—production—consumption—waste) to a closed circuit. The document introduces concepts such as extended producer responsibility (EPR), which requires a change in the approach of entrepreneurs to design a product from the very beginning with the intention of reusing parts or simplifying the recycling process. The proposed approaches are analyzed in many aspects and provide for close cooperation between ministries (Minister of the Environment, Minister for the Economy, Minister for Information Technology) to effectively implement changes [37].

According to the document, the most important undertakings will be works related to [37]:

- unification of legal provisions regarding biomass, including developing materials and models for calculating the impact of products and economic activities on the environment (LCA-life cycle assessment);

- increasing consumer awareness to support products manufactured in accordance with the circular economy;

- creating a framework and setting directions at a central and local level;

- creating local value chains and resource base;

- campaigns on the principle of cascading approach in the usage of biomass;

- comprehensive analysis of bioeconomy barriers;

- creating norms and standards for particular categories of products made from biomass;

- changes in the tax system enabling the increase of competitiveness of enterprises operating according to the philosophy of the circular economy.

The need for changes in biomass processing is also emphasized-the road map assumptions point out that the energetic purposed are not one of the pillars of the circular economy and the value of biomass should be maximized due to the activities planned for 2020-2023. The road map is also aiming at solving the above-mentioned problem regarding the waste status and introducing new legal provisions, enabling easier re-use of valuable by-products from biomass processing.

\section{Conclusions}

Each country should strive for a circular economy and minimize waste generated by society and industry. Such an opportunity is offered by new technologies for the use of waste from agriculture, food processing and many other branches of industry to extend the chain of biomass products. The Polish South Baltic Area, consisting of the Pomeranian, West Pomeranian and Warmia and Mazury regions, has a wide potential in terms of the produced agricultural biomass, giving many opportunities; however, differences between regions show how individual approaches to each of these areas are required. The activities undertaken under the Regional Operational Programs 2014-2020 show that it is necessary to "align" the level of advancement of the infrastructure before large-scale activities for the development of biomass reuse for purposes other than energy are undertaken in individual regions. In the programs for the coming years, however, it is necessary to start decisive actions to support and encourage the development of projects in the field of extending the biomass processing chain, coordinated with the government's actions to unify the law in this matter.

Apart from the need to level the differences between regions, the most important barrier to the implementation of the circular economy, not only in the Baltic regions but also throughout Poland, is the lack of an appropriate legal framework. This is to be changed by the Circular Economy Road 
Map, adopted in 2019, announcing a number of changes and facilitation regarding the re-use of biomass waste. The map has a wide range of activities, but as the entrepreneurs emphasize, the most important thing is to facilitate and simplify the initial path, i.e., to facilitate the change of waste status into raw material. The current legal provisions make it even more difficult to change this status and block the re-use of waste as a raw material in another process, and the long administrative path discourages entrepreneurs from taking action in this matter.

Author Contributions: Conceptualization, D.M.; Data curation, P.D. and A.G.; Formal analysis, P.D., R.B. and A.G.; Funding acquisition, D.M.; Investigation, P.D. and R.B.; Methodology, D.M.; Project administration, D.M.; Resources, D.M.; Software, A.G.; Supervision, D.M.; Validation, P.D. and R.B.; Visualization, R.B.; Writing—original draft, P.D., R.B. and A.G.; Writing-review and editing, D.M. All authors have read and agreed to the published version of the manuscript.

Funding: The work presented in this paper was funded from the Interreg South Baltic Programme 2014-2020, project: STHB.01.02.00-DK-0086/16-00 "Bioeconomy in the South Baltic Area: Biomass-based Innovation and Green Growth" (BioBIGG) in the years 2017-2020.

Conflicts of Interest: The authors declare no conflict of interest.

\section{References}

1. European Commission, Directorate-General for Research and Innovation. A Sustainable Bioeconomy for Europe: Strengthening the Connection between Economy, Society and the Environment: Updated Bioeconomy Strategy; Publications Office of the European Union: Luxembourg, 2018.

2. Von Braun, J. Bioeconomy-The global trend and its implications for sustainability and food security. Glob. Food Secur. 2018, 19, 81-83. [CrossRef]

3. United Nations. Paris Agreement under the United Nations Framework Convention on Climate Change. November 2016. Available online: https://unfccc.int/sites/default/files/english_paris_agreement.pdf (accessed on 20 September 2020).

4. United Nations. Transforming Our World: The 2030 Agenda for Sustainable Development. General Assembly. 25 September 2015. Available online: https:/www.un.org/en/development/desa/population/migration/ generalassembly/docs/globalcompact/A_RES_70_1_E.pdf (accessed on 20 September 2020).

5. Kirchherr, J.; Reike, D.; Hekkert, M. Conceptualizing the circular economy: An analysis of 114 definitions. Resources. Conserv. Recycl. 2017, 127, 221-232. [CrossRef]

6. Hartley, K.; Van Santen, R.; Kirchherr, J. Policies for transitioning towards a circular economy: Expectations from the European Union (EU). Resour. Conserv. Recycl. 2020, 155, 104634. [CrossRef]

7. Michelini, G.; Moraes, R.N.; Cunha, R.N.; Costa, J.M.H.; Ometto, A.R. From Linear to Circular Economy: PSS Conducting the Transition. Procedia CIRP 2017, 64, 2-6. [CrossRef]

8. Marino, A.; Pariso, P. Comparing European countries' performances in the transition towards the Circular Economy. Sci. Total Environ. 2020, 729, 138142. [CrossRef] [PubMed]

9. Kirchherr, J.; Piscicelli, L.; Bour, R.; Kostense-Smit, E.; Muller, J.; Huibrechtse-Truijens, A.; Hekkert, M. Barriers to the Circular Economy: Evidence From the European Union (EU). Ecol. Econ. 2018, 150, 264-272. [CrossRef]

10. Carus, M.; Dammer, L. The "Circular Bioeconomy"-Concepts, Opportunities and Limitations. Available online: https://bioplasticfeedstockalliance.org/wp-content/uploads/2020/01/External_Resource_ Nova_Paper_9_The_Circular_Bioeconomy.pdf (accessed on 22 September 2020).

11. Stegmann, P.; Londo, M.; Junginger, M. The circular bioeconomy: Its elements and role in European bioeconomy clusters. Resour. Conserv. Recycl. 2020, 6, 100029. [CrossRef]

12. European Commission. The European Green Deal. Available online: https:/ec.europa.eu/info/strategy/ priorities-2019-2024/european-green-deal_en (accessed on 22 September 2020).

13. European Commission. A New Circular Economy Action Plan for a Cleaner and More Competitive Europe. Available online: https://ec.europa.eu/environment/circular-economy/ (accessed on 22 September 2020).

14. The National Assembly. The Constitution of the Republic of Poland of April 2, 1997. Journal of Laws 1997 No.78, item. 483. Available online: https://www.sejm.gov.pl/prawo/konst/angielski/kon1.htm (accessed on 22 September 2020). 
15. Marshal of the Sejm. Announcement of the Marshal of the Sejm of the Republic of Poland of 19 July 2019 Regarding the Publication of a Uniform Text of the Act-Environmental Protection Law. 2019. Available online: https://isap.sejm.gov.pl/isap.nsf/download.xsp/WDU20200001219/U/D20201219Lj.pdf (accessed on 22 September 2020).

16. The Council of Ministers. Resolution No. 8 of the Council of Ministers of 14 February 2017 Regarding the Adoption of the Strategy for Responsible Development until 2020 (with a Perspective until 2030). Available online: http://isap.sejm.gov.pl/isap.nsf/download.xsp/WMP20170000260/O/M20170260.pdf (accessed on 22 September 2020).

17. The Council of Ministers. Resolution No. 102 of the Council of Ministers of 17 September 2019 Regarding the Adoption of the "National Strategy for Regional Development 2030". Available online: http://isap.sejm. gov.pl/isap.nsf/download.xsp/WMP20190001060/O/M20191060.pdf (accessed on 22 September 2020).

18. The Council of Ministers. Resolution No. 67 of the Council of Ministers of 16 July 2019 Regarding the Adoption of the "2030 Ecological Policy of the State-Development Strategy in the Area of Environment and Water Management". Available online: http://isap.sejm.gov.pl/isap.nsf/download.xsp/WMP20190000794/O/ M20190794.pdf (accessed on 22 September 2020).

19. The Council of Ministers. Resolution No. 88 of the Council of Ministers of 1 July 2016 Regarding the National Waste Management Plan 2022. Available online: http://isap.sejm.gov.pl/isap.nsf/download.xsp/ WMP20160000784/O/M20160784.pdf (accessed on 22 September 2020).

20. Parliament of Poland. Act of 14 December 2012 on Waste. Journal of Laws of 2013, Item 21. Available online: https://isap.sejm.gov.pl/isap.nsf/download.xsp/WDU20130000021/U/D20130021Lj.pdf (accessed on 22 September 2020).

21. The Council of Ministers. Resolution No. 123 of the Council of Ministers of 15 October 2019 Regarding the Adoption of the "2030 Sustainable Rural Development Strategy for Agriculture and Fisheries". Available online: http://gamma.infor.pl/zalaczniki/mpo/2019/213/mpo.2019.213.1150.0001.pdf (accessed on 22 September 2020).

22. Statistical Office in Szczecin. Statistical Yearbook of Zachodniopomorskie Voivodship; GUS (Central Statistical Office): Szczecin, Poland, 2019; ISSN 1640-0038.

23. Statistical Office in Gdańsk. Statistical Yearbook of Pomorskie Voivodship; GUS (Central Statistical Office): Gdańsk, Poland, 2019; ISSN 1640-0046.

24. Statistical Office in Olsztyn. Statistical Yearbook of Warmińsko-Mazurskie Voivodship; GUS (Central Statistical Office): Olsztyn, Poland, 2019; ISSN 1640-0070.

25. Statistical Office in Szczecin. Agriculture in Zachodniopomorskie Voivodship in 2018; GUS (Central Statistical Office): Szczecin, Poland, 2019.

26. Statistical Office in Gdańsk. Agriculture in Pomorskie Voivodship in 2018; GUS (Central Statistical Office): Gdańsk, Poland, 2019.

27. Statistical Office in Olsztyn. Agriculture in Warmińsko-Mazurskie Voivodship in years 2018-2019; GUS (Central Statistical Office): Olsztyn, Poland, 2020; ISBN 978-83-63285-70-8.

28. Statistics Poland. Statistical Yearbook of the Republic of Poland; GUS (Central Statistical Office): Warsaw, Poland, 2019; ISSN 1506-0632.

29. Osman, A.I.; Abdelkader, A.; Farrell, C.; Rooney, D.; Morgan, K. Reusing, recycling and up-cycling of biomass: A review of practical and kinetic modelling approaches. Fuel Process. Technol. 2019, 192, 179-202. [CrossRef]

30. Keegan, D.; Kretschmer, B.; Elbersen, B.; Panoutsou, C. Cascading use: A systematic approach to biomass beyond the energy sector. Biofuels Bioprod. Biorefining 2013, 7, 193-206. [CrossRef]

31. Marshal Office of the Pomeranian Region. A Detailed Description of the Priority Axes of the Regional Operational Program of the Pomeranian Region for 2014-2020. Available online: https: //www.rpo.pomorskie.eu/documents/10184/108777/Szczeg\%c3\%b3\%c5\%82owy+Opis+Osi+Priorytetowych+ RPO+WP+2014-2020.pdf/02e757a1-a9be-45bf-8945-91888c70b646 (accessed on 23 September 2020).

32. Marshal Office of the Warmia and Mazury Region. A Detailed Description of the Priority Axes of the Regional Operational Program of the Warmia and Mazury Region for the Years 2014-2020. Available online: https://rpo.warmia.mazury.pl/plik/3/regionalny-program-operacyjny-wojewodztwawarminsko-mazurskiego-na-lata-2014\%E2\%80\%932020 (accessed on 23 September 2020). 
33. Marshal Office of the West Pomeranian Region. A Detailed Description of the Priority Axes of the Regional Operational Program of the West Pomeranian Region for the Years 2014-2020. Available online: https: //www.funduszeeuropejskie.gov.pl/media/87932/RPO_wz_17032020.pdf (accessed on 23 September 2020).

34. Grants map EU. Available online: www.mapadotacji.gov.pl (accessed on 23 September 2020).

35. Jiang, L.; Zhang, J.; Wang, H.H.; Zhang, L.; He, K. The impact of psychological factors on farmers' intentions to reuse agricultural biomass waste for carbon emission abatement. J. Clean. Prod. 2018, 189, 797-804. [CrossRef]

36. Majcher, A.; Kursa, L. Business Tendency on Farms in the First Half of 2019; Statistics Poland: 2019. Available online: https://stat.gov.pl/obszary-tematyczne/rolnictwo-lesnictwo/rolnictwo/koniunktura-wgospodarstwach-rolnych-w-pierwszym-polroczu-2019-roku,10,14.html (accessed on 23 September 2020).

37. The Council of Ministers. Roadmap for Transformation towards a Circular Economy. Annex to the Resolution of the Council of Ministers; Poland, 2019. Available online: https://www.gov.pl/web/rozwojpraca-technologia/rada-ministrow-przyjela-projekt-mapy-drogowej-goz (accessed on 23 September 2020).

Publisher's Note: MDPI stays neutral with regard to jurisdictional claims in published maps and institutional affiliations.

(C) 2020 by the authors. Licensee MDPI, Basel, Switzerland. This article is an open access article distributed under the terms and conditions of the Creative Commons Attribution (CC BY) license (http://creativecommons.org/licenses/by/4.0/). 